\title{
Limitations Clauses, Evidence, and the Burden of Proof in the European Court of Human Rights
}

\author{
T. Jeremy Gunn \\ International University of Rabat \\ Jeremy.gunn@uir.ac.ma
}

\begin{abstract}
Courts and tribunals involved in evaluating whether states have applied limitations clauses appropriately should pay increased attention to the core underlying issues of the parties' respective burdens of proof, the standards of proof, and identifying which parties are required to prove which assertions. The European Court of Human Rights has not articulated with sufficient clarity the rules of evidence that apply to its proceedings, thereby permitting ad hoc and inconsistent evaluations of issues pertaining to the freedom of religion or belief. The Court should take seriously its obligation to clarify its standards and thereafter apply them.
\end{abstract}

\section{Keywords}

freedom of religion or belief - limitation clauses - evidence - burden of proof European Court of Human Rights - revising the Rules of Court - inquisitorial and adversarial

\section{Introduction}

Each of the articles in this special volume acknowledges the fundamental importance of the right to freedom of religion and belief and all articulate concerns about how limitations regarding the right are interpreted and applied, whether by courts, legislatures, or other institutions. The articles encompass the international realm, the regional level, emphasizing the European Convention on Human Rights (ECHR), as well as six specific states (Indonesia, Brazil, Nigeria, Georgia, Turkey, and Denmark), the latter three of which also 
are signatories to the ECHR. The articles call for a more serious analysis and application of what should be the underlying and governing principles surrounding legitimate limitations on the freedom of religion or belief in both international and domestic law.

While largely agreeing with the critiques and objections of the several authors in this volume, I would like to identify one significant additional issue that is not addressed explicitly by the authors: the absence of a consistent and rigorous judicial method regarding the evaluating of evidence and of establishing the relative burdens of proof of the parties in limitations adjudication. I will suggest that the European Court, arguably the world's single most important human rights tribunal, has no consistent approach to the handling of evidence or the burdens of proof in its limitations analysis. This lack of such standards ultimately leads to inconsistent decision-making and, in effect, to the undermining of rights guaranteed in human rights instruments. In the context of religion cases, such a lack of discipline in the Court's jurisprudence effectively undermines the rights guaranteed by the ECHR and benefits/gives the advantage to states, thereby eliciting the exact type of problem identified (from their different perspectives) by Bielefeldt and Alves Pinto.

Although this article focuses largely on the procedures and standards of the European Court of Human Rights (Court or European Court), it is believed that the analysis and proposals may be applied, mutatis mutandis, to other international systems as well as to states. I will begin by assuming, rather than arguing or elaborating here, two fundamental points of international and domestic law that have been argued by the authors: first, that the freedom of religion or belief is a fundamental right of individuals and communities, and second, that international standards as articulated in the texts of international conventions, mandate that limitations to the freedom of religion or belief should be applied only in sharply defined narrow circumstances consistent with law. ${ }^{1}$ These two points are not without controversy, but this is not the moment to engage that issue. Rather than providing the details of my criticisms here, I refer readers to earlier publications where I addressed these issues more directly. ${ }^{2}$

1 Heiner Bielefeldt and Thiago Alves Pinto articulate these points well in their articles; respectively Heiner Bielefeldt, 'Limiting Permissible Limitation: How to Preserve the Substance of Religious Freedom', and Thiago Alves Pinto, 'An Empirical Investigation of the Use of Limitations to Freedom of Religion or Belief at the European Court of Human Rights', included in this issue.

2 T.Jeremy Gunn, 'Permissible Limitations on the Freedom of Religion or Belief', in John Witte Jr. and M. Christian Green (eds), Religion and Human Rights: An Introduction (Oxford: Oxford University Press, 2011); 'Deconstructing Proportionality in Limitations Analysis', Emory International Law Review 19 (2005): pp. 465-98; 'Introduction (to Symposium Issue on 
Ultimately, I find that the European Court's handling of evidence reveals a fundamental flaw in how the Court decides whether to allow states to infringe on the right to freedom of religion or belief. Here I will provide one simple example that contrasts the Court's use of evidence in two different cases involving religious symbols in public schools. The first case was the 2001 admissibility decision of Dahlab v. Switzerland, involving the right of a Muslim elementary school teacher to wear a headscarf while teaching in the classroom. The second is the 2011 Grand Chamber decision, Lautsi v. Italy, where non-Catholic parents of school children challenged an Italian law requiring the placement of the Christian crucifix on the walls of all public-school classrooms. In Dahlab, a primary school teacher in Geneva wore the headscarf for years without any complaint by her students or by their parents. The decision to forbid the teacher from wearing a headscarf was made by school administrators because of their objections rather than the objections of parents or children. In Lautsi, parents of some students complained that their own children were being subjected to state religious propaganda that violated Article 9 ECHR and Article 2 of ECHR Protocol 1 ('the State shall respect the right of parents to ensure such education and teaching in conformity with their own religious and philosophical convictions').

To the extent that the Court's interest was in protecting the right of parents (or students) not to have children subjected to unwanted religious symbols in public school classrooms, the prima facie evidence in both cases is immediate and clear: there were no complaints by students (or parents) to the headscarf in Dahlab while there were strenuous objections in Lautsi. Thus the prima facie evidence supports both Ms. Dahlab and the Lautsis. Nevertheless, the European Court's decisions were exactly the opposite of what the initial evidence suggested: Ms. Dahlab's right to wear a headscarf was not supported and the Italian state was authorized to post the crucifix in all public school classrooms. In Dahlab, the Court decided that the wearing of the scarf might possibly have an adverse effect on students while in Lautsi the Court decided that the crucifix definitely would not have any adverse effects on students.

the Permissible Scope of Legal Limitations on the Freedom of Religion or Belief)', Emory International Law Review 19 (2005): pp. ix-xviii; and 'Fearful Symbols: The Islamic Headscarf and the European Court of Human Rights in Sahin v. Turkey', Droit et Religion (2008): pp. 339-67. 
In Dahlab, the Court acknowledged that there was in fact no evidence presented that any child was harmed, affected, or even conscious of any religious significance of their Muslim teacher's wearing the scarf. The Canton's school inspector acknowledged that 'she had never had any comments from parents on the subject.' ${ }^{3}$ Thus, the actual evidence before the Court was that there had been no complaints by parents or students regarding Ms. Dahlab's wearing of the headscarf. Additionally, the Court recited no evidence presented to it by the school or the state of any harmful effect on students and therefore failed to satisfy its (hypothetical) burden of proof. If it were understood that the state had the burden of proof before the Court, the state failed to offer any evidence of a harmful effect on students. Despite the implicit evidence to the contrary (there having been no complaints), the European Court, on its own initiative, speculated with regard to the possible effect that the headscarf might have:

The Court accepts that it is very difficult to assess the impact that a powerful external symbol such as the wearing of a headscarf may have on the freedom of conscience and religion of very young children. The applicant's pupils were aged between four and eight, an age at which children wonder about many things and are also more easily influenced than older pupils. In those circumstances, it cannot be denied outright that the wearing of a headscarf might have some kind of proselytising effect, seeing that it appears to be imposed on women by a precept which is laid down in the Koran ... Accordingly, weighing the right of a teacher to manifest her religion against the need to protect pupils by preserving religious harmony, the Court considers that, in the circumstances of the case and having regard, above all, to the tender age of the children for whom the applicant was responsible as a representative of the State, the Geneva authorities did not exceed their margin of appreciation and that the measure they took was therefore not unreasonable. ${ }^{4}$

These remarkable paragraphs, which inter alia demonstrate an ignorance of Islam and the Quran, do not provide evidence to justify the Court's decision. To be noted, the Court refers to the headscarf as a "powerful external symbol". Powerful to whom? Apparently not to Ms. Dahlab's students. Why is it a "religious symbol"? Why is not a simple statement of modesty similar to a woman's decision not to expose her breasts or thighs? Would covering those body parts

3 Dahlab v. Switzerland, 15 February 2001, ECtHR, No. 42393/98. p. 1 [official translation].

4 Dahlab v. Switzerland, 15 February 2001, ECtHR, No. 42393/98, p. 13 [official translation] (emphasis added). 
be a "powerful external symbol"? What is the Court's evidence in support of its provocative observations? Most tellingly, in the absence of evidence, the Court reaches into its own sentiments to find that the headscarf "might" have a proselytizing effect as if the mere possibility—-without actual evidence-is enough to nullify the right to manifest religion that is explicitly guaranteed by the ECHR. If Courts are permitted to use the speculative "might" rather than actual evidence, they similarly could find anticipatory breaches of contract, render convictions for what is in people's minds, and dozens of other events that "might" happen.

In Dahlab, the Court was concerned about the lack of state neutrality if a teacher wore a headscarf. It noted with approval the state's "principle of denominational neutrality" and the "legitimate aim of ensuring the neutrality of the State educational system". ${ }^{5}$ In Lautsi, a much clearer case of a lack of state neutrality presented itself, but the European Court was apparently uninterested.

The Lautsi case arose in response to an Italian law that required the placement of the Christian crucifix in all public school classrooms in Italy. ${ }^{6}$ The Minister of Education, in the government of Silvio Berlusconi, cited as his authority for issuing Directive 2666 two laws promulgated during the fascist rule of Benito Mussolini. ${ }^{7}$

The crucifix is a three-dimensional representation of the suffering body of Jesus Christ, nailed to the cross, at the time of his death. In Christian scripture, this is the moment at which 'Jesus, crying with a loud voice, said, "Father, into your hands I commend my spirit." Having said this, he breathed his last.' In

5 Ibid., p. 12.

6 Directive 2666 issued by the Italian Ministry of Education, Universities and Research, 3 October 2002.

7 Article 118 of Royal Decree No. 965 of 30 April 1924 and Article 119 of Royal Decree No. 1297 of 26 April 1928, governing middle schools and primary schools respectively. Mussolini was, of course, an atheist and ferocious anti-Catholic who nevertheless cynically instrumentalized the crucifix to advance his own political agenda that had nothing to do with reverence for the suffering of Christ. In an equally cynical gesture, the Italian Minister of Education in 2002 resurrected the Fascist-era law and asserted that the 'crucifix symbolised the principles and values which formed the foundation of democracy and western civilisation, and that its presence in classrooms was justifiable on that account'. Lautsi and Others v. Italy, 18 March 2011, ECtHR, Grand Chamber, No. 30814/o6, para. 69. Silvio Berlusconi is known less for his religious convictions and more for his criminal convictions on the grounds of corruption, bribery of witnesses, tax fraud, and for his sexual relations with underage Ruby Rubacuori.

8 Luke 23:46 NRSV. 
accepting this burden, Jesus took upon himself the physical suffering for all of the sins of the world and then gave his life so that human beings could be resurrected and gain eternal life. For many Christians, the crucifix depicts one of the two, transcendent moments of their religion.

In Dahlab, the Court decided against the applicant based upon its speculation that the wearing of a headscarf might have an effect on impressionable children. But in Lautsi, where the religious symbolism of the crucifix was obvious, the Court completely reversed its evidentiary approach:

There is no evidence before the Court that the display of a religious symbol on classroom walls may have an influence on pupils and so it cannot reasonably be asserted that it does or does not have an effect on young persons whose convictions are still in the process of being formed. ${ }^{9}$

It is remarkable for the Court to state that there was "no evidence" of an adverse effect when the Court was confronted by actual parents and children who were complaining about the religious symbol. Whereas in Dahlab the absence of social-scientific evidence allowed the Court to presume an impermissible influence on children, in Lautsi the absence of such evidence allowed the Court to presume exactly the opposite social-scientific assumption.

The Court thereupon dismissed the "applicant's subjective perception":

However, it is understandable that the first applicant might see in the display of crucifixes in the classrooms of the State school formerly attended by her children a lack of respect on the State's part for her right to ensure their education and teaching in conformity with her own philosophical convictions. Be that as it may, the applicant's subjective perception is not in itself sufficient to establish a breach of Article 2 of Protocol No. $1^{10}$

Ironically, in trivializing the "applicant's subjective perception", the Court itself did exactly that for which it had dismissed the applicants: offering its own subjective perception of the meaning of the cross. Thus we have a core evidentiary problem: the absence of evidence allows the Court to reach not evidencebased decisions, but offer instead its unsupported speculative inferences.

$9 \quad$ Ibid., para. 66. (emphasis added)
10 Ibid. 
Among the terms related to evidence that appear in the Court's jurisprudence (including French terms whose meanings often are not equivalent to the words they resemble in English) are: "evidence", "preuves", "proof", "the burden of proof", "charge (or fardeau) de la preuve", "the burden of persuasion", "the burden of presenting a prima facie case", "the burden of presenting evidence", "he who asserts must prove" (actori incumbit probatio), "shift the burden of proof", "renverser le charge de la preuve", "the standard of proof", "beyond reasonable doubt", and "conviction intime". ${ }^{11}$ Other terms that are not used by the European Court, but that are familiar to jurists in the Common Law tradition, include: "balance of probabilities", "the preponderance of evidence", and the "party best situated to provide evidence", "more likely than not", and "clear and convincing”. Rules governing the introduction and evaluation of evidence can be difficult in any jurisdiction, and they can be complicated by a regional court (like the European Court) that not only evaluates laws and practices from different jurisdictions, but which is comprised of judges that come from different jurisdictions, and who have differing degrees of familiarity with the English and French languages in which the Court operates, particularly if the European judges learned legal English in Great Britain, the United States, Canada, or Australia. Although some difficulties come no doubt from language translations and from the often false equivalencies among terms, they may point to the even greater problem of the Court's being clear about what exactly its role is when deciding whether a right has been infringed, or whether the state has provided sufficient evidence (preuves) to justify its "purpose" in limiting the right, or whether the limitation is "proportionate" to the goal pursued by the state.

Let us take two examples from among the terms identified above to illustrate briefly the potential confusion that may arise as the Court grapples, consciously or unwittingly, with the legal standards to be employed.

\subsection{Proof, Evidence, Preuve}

In a general way, "evidence" in English may be translated as "preuve" in French. At the same time, the English word "proof" similarly is translated into "preuve" in French. However, in English, "proof" typically is not entirely synonymous

\footnotetext{
11 The standard English-French dictionary used by the Court, Lexique Anglais-Français $d u$ Conseil de l'Europe $(1993,2002)$ does not itself probe the important legal differences in nuance between the two languages.
} 
with the English term "evidence". This leads to a problem in what might be called back translation. Let me provide an example of the problem. In 1967, French President Charles DeGaulle gave a speech in Canada where he said "Vive le Québec libre." This is translated into English as "Long-live free Quebec." But if one translates the English free back into French, there are (at least) two different French words that might be employed: either libre (as intended by DeGaulle) or gratuit (which means "at no cost" or "cost-free", as when a merchant gives "free samples" to her customers). While no competent translator would make the mistake of mistranslating the English free back into the French gratuit, the possibility remains for someone less knowledgeable. This easily recognizable error of libre $=$ free $=$ gratuit is perhaps less obvious when the English evidence is translated into the French preuve.

In brief, the English word "evidence" typically refers to a piece of evidence such as a fact, document, or witness testimony in support of an argument, while the English "proof" is more likely used to convey the totality of the evidence in favor of an argument. "Have you satisfied your burden of proof?" means something like "have you provided a sufficient amount of evidence to convince the court of your argument?" This is complicated further by the fact that the French word "évidence" (which is largely not part of the French legal vocabulary) may be translated into the English terms "obvious" or "certain". In short, the English proof is typically used for the entire sum of the evidence, whereas the French "preuve" pertains more to an individual fact or one piece of evidence.

\section{2 "Proof beyond a Reasonable Doubt"}

A second and even more complicated term from the Court's jurisprudence is "proof beyond a reasonable doubt" (translated into French by the Court as: la "preuve de l'intime conviction"). Jurists in the Common Law tradition are likely to (mis)understand the term as a reference to the heightened evidentiary standard that is requisite in criminal trials for the conviction of the accused. Although Court has repeatedly stated that the Common Law meaning of "proof beyond a reasonable doubt" is not the meaning as used by the European Court (see further below), it has not been entirely clear as to exactly what the term means or in which circumstances it should be applied. One might reasonably choose either of the two following possible meanings of the term when employed by the Court: first, as a standard of proof only in more extreme cases of deprivation of life or personal liberty (such as under Article 3 of the ECHR), or second, as the basic standard of proof for all elements in cases that come before the Court. The difference in scope between the first and second possible 
usages is, of course, substantial, but the Court has not explained clearly whether there is more than one standard of proof and in which cases it applies. ${ }^{12}$

\section{The ECH R's de Facto “Evidentiary Guidelines"}

Separately from articulating its "beyond reasonable doubt" standard, the Court has vaguely articulated the norms under which it evaluates evidence. One of the more complete and recent explanations of the Court's understanding of evidence appeared in the 2014 case Husayn (Abu Zubaydah) v. Poland. Although the following excerpt from Husayn is somewhat lengthy, it touches upon most of the core issues related to the Court's perceived responsibilities and roles with regard to evidence. Brackets, enumeration, and italicizing have been added to emphasize and differentiate the separate and important points made by the Court:

393. [1] The Court is sensitive to the subsidiary nature of its role and has consistently recognised that it must be cautious in taking on the role of a first-instance tribunal of fact, where this is not rendered unavoidable by the circumstances of a particular case.

394. In assessing evidence, [2] the Court has adopted the standard of proof "beyond reasonable doubt". However, [3] it has never been its purpose to borrow the approach of the national legal systems that use that standard. Its role is not to rule on criminal guilt or civil liability but on Contracting States' responsibility under the Convention. The specificity of its task under Article 19 of the Convention-to ensure the observance by the Contracting States of their engagement to secure the fundamental rights enshrined in the Convention-conditions its approach to the issues of evidence and proof. [4] In the proceedings before the Court, there are no procedural barriers to the admissibility of evidence or predetermined formulae for its assessment. It adopts the conclusions that are, in its view, supported by the [5] free evaluation of all evidence, including such inferences as may flow from the facts and the parties' submissions.

12 The Court first employed the "beyond reasonable doubt" standard in the Greek Case (1969), which arose out of Article 3 of the Convention. It reiterated this in what may be seen as the leading case, Ireland v. The United Kingdom, 18 January 1978, ECtHR, No. 5310/71, which also was an Article 3 case. The Court has subsequently used the standard in regard to other ECHR articles, but has never stated clearly that it applies to all cases or only depravation of personal liberty and life. 
According to the Court's established case-law, proof may follow from the coexistence of [6] sufficiently strong, clear and concordant inferences or of similar unrebutted presumptions of fact. Moreover, [7] the level of persuasion necessary for reaching a particular conclusion and, in this connection, [8] the distribution of the burden of proof, [9] are intrinsically linked to the specificity of the facts, the nature of the allegation made and the Convention right at stake. The Court is also attentive to the seriousness that attaches to a ruling that a Contracting State has violated fundamental rights. [10] While it is for the applicant to make a prima facie case and adduce appropriate evidence, [11] if the respondent Government in their response to his allegations fail to disclose crucial documents to enable the Court to establish the facts or otherwise provide a satisfactory and convincing explanation of how the events in question occurred, strong inferences can be drawn.

396. Furthermore, the [12] Convention proceedings do not in all cases lend themselves to a strict application of the principle affirmanti incumbit probatio. According to the Court's case-law under Articles 2 and 3 of the Convention, where the events in issue lie wholly, or in large part, within the exclusive knowledge of the authorities [...] [t] he burden of proof in such a case may be regarded as resting on the authorities to provide a satisfactory and convincing explanation.

In the absence of such explanation the Court can draw inferences which may be unfavourable for the respondent Government. ${ }^{13}$

Nevertheless, this passage from Husayn offers a remarkable statement, or perhaps more appropriately "admission" from the Court that, at root, it has not yet developed a sophisticated, comprehensive, or coherent approach to evidence, standards of proof, or burdens of proof. From these twelve enumerated points the Court is left free to listen to its own inner voice and is free to accept or reject evidence as it wishes and without holding any party accountable for providing evidence. These twelve points are less an articulation of a procedure as they are a candid admission that whatever the Court says regarding evidence is the governing rule.

13 Husayn (Abu Zubaydah) v. Poland, 24July 2014, ECtHR, No. 7511/13 (emphasis and brackets added). From this author's reading, Husayn neatly summarizes and is largely consistent with the Court's articulated approach to evidence and burdens. This is not to say that the Court always followed these standards. 

Procedure?

A distinguishable, but interrelated question, is whether the European Court understands itself to be acting as an "inquisitorial" court (typical in the Civil Law tradition) or as a "neutral" court as in an adversarial system (typical in the Common Law tradition). While at first this question may not appear to be immediately pertinent to the question of limitations clauses under the ECHR, it may nevertheless contribute to our understanding of the discrepancy in decisions such as Dahlab and Lautsi.

If the Court acts as if it had an inquisitorial role, it bears the responsibility of seeking out evidence from the parties and allows itself the right to "draw inferences which may be unfavourable", as stated in point [12] above, for the failure of a party to provide the requisite evidence. Parties not responding to reasonable requests for information may have adverse inferences drawn against them. On the other hand, if the Court perceives itself as presiding over an adversarial system, it may blame the parties for having failed to prove their case to the satisfaction of the Court. ${ }^{14}$ So which type of Court is it?

Unfortunately, the answer to this question also is confused (and perhaps contradictory). The most obvious presumption is that the European Court would consider itself to be inquisitorial and the organ for soliciting evidence from the parties. The scholar who arguably has evaluated most closely the Court's approach to evidence concludes that it considers itself to be inquisitorial: 'the Court's proceedings are also largely inquisitorial in nature.' ${ }^{15}$ Juliane Kokott, in her book comparing standards of proof in state and international jurisprudence, concludes that the European Court either is (or particularly in cases of jus cogens should be) inquisitorial. ${ }^{16}$ Kanstantsin Dzehtsiarou applauds the Court for (sometimes) taking seriously its inquisitorial role: 'While the ECtHR mainly relies on evidence provided by the parties, in some cases it actively seeks to establish facts through fact-finding missions, in-house research, [and] requesting documents and explanations. ${ }^{17}$ Dzehtsiarou, who

14 The vagueness of the Court's evidentiary guidelines may again be noted.

15 Tobias Thienel, 'The Burden and Standard of Proof in the European Court of Human Rights', 50 German Yearbook of International Law (2007), p. 547.

16 Juliane Kokott, The Burden of Proof in Comparative and Interantional Human Rights Law: Civil and Common Law Approaches with Special Reference to the American and German Legal Systems (The Hague: Kluwer Law International, 1998) (see especially chapter 3).

17 Kanstantsin Dzehtsiaro, European Consensus and the Legitimacy of the European Court of Human Rights (Cambridge: Cambridge University Press, 2015), pp. 89-9o. 
believes that the Court is fully authorized to engage actively in finding facts, nevertheless suggests that it may not always be wise. His ambivalence provides a segue to the conflicting view that the Court's proper role should be that of neutrally presiding over an adversarial proceeding and play a limited role in fact-finding.

Indeed the Court often appears to take a rather passive role in not insisting on the production of evidence and in not chiding the parties for not having provided it with the requisite evidence. With reference to Lautsi, we could ask why did the Court not draw an adverse presumption against the state in the absence of Italy's failing to provide evidence that there was no effect on the children with the display of the crucifix?

Yet there also are suggestions that the Court should better be understood as presiding over an adversarial system. Perhaps the clearest mark of this comes directly from the Council of Europe itself with regard to the important 2004 amendments to the ECHR known as Protocol 14, which completely restructured the European Court of Human Rights. As is standard policy in the Council of Europe whenever a new treaty, treaty amendments, or additional protocol is proposed, the Council of Europe establishes an expert group to issue an "Explanatory Report" to articulate the rationale behind the new treaty or amendments. For Protocol 14, the "Drafting Group on the Reinforcement of Human Rights Protection Mechanism" prepared the Explanatory Report. ${ }^{18}$ Comprising the leading Council of Europe experts on the topic, the Drafting Group offered its professional judgment on the role of the Court. Rather than characterizing the Court as being inquisitorial, the experts described the new procedures as preserving the Court's pre-existing adversarial system.

The new procedure [under Protocol 14] is both simplified and accelerated, although it preserves the adversarial character of proceedings and the principle of judicial and collegiate decision making on the merits. Compared to the ordinary adversarial proceedings before a Chamber, it will be a simplified and accelerated procedure in that the Court will simply bring the case (possibly a group of similar cases) to the respondent Party's attention, pointing out that it concerns an issue which is already the subject of well-established case-law. ${ }^{19}$

\footnotetext{
18 CoE, Explanatory Report to Protocol No. 14 to the Convention for the Protection of Human Rights and Fundamental Freedoms, Amending the Control System of the Convention (CoE Treaty Series No. 194). 
The experts thus evidently understood that the European Court already operated an adversarial system that would continue, albeit in a more refined manner. The experts went on to characterize admissibility decisions as well as decisions on the merits as "respecting fully the principle of adversarial proceedings". ${ }^{20}$ Although the opinions of the experts are not binding on the Court, they are the experts who prepared and ultimately implemented Protocol 14. One of the leading outside authorities on the ECHR, Professor William Schabas, concurs with the assessment of the Protocol 14 experts. ${ }^{21}$ It also is to be noted that the European Court is not in principle opposed to adversarial proceedings, and, indeed its own Court Rules call upon the application of adversarial proceedings in cases of friendly settlements where both sides must be present and agree in a public setting. ${ }^{22}$

We might reasonably conclude that if the Court has not articulated and does not follow any developed guidelines regarding the burden of proof or the standard of proof, and similarly does not have a clear understanding of its own role as a Court, we might well understand why its decisions lack the rigor and consistency that we should expect from a Court deciding fundamental human rights cases.

The ways in which evidence is handled by a Court along with procedures for handling the burdens of proof and the standards of proof can be outcome determinative. There is a difference between a court's concluding that an applicant or respondent has failed to provide sufficient evidence to support its case and a court deciding cases based upon its own speculation about what the evidence might have been-and reaching exactly opposite speculations as in Dahlab and Lautsi. Because the Court is deciding cases involving the fundamental rights of human beings, it should be rigorous and consistent in its approach to evidence and not make evidentiary decisions on an ad hoc or impressionistic way.

\footnotetext{
$20 \quad$ Ibid., para. 73 .

21 William Schabas, The European Convention on Human Rights: A Commentary (Oxford: Oxford University Press, 2015), p. 703.

22 See CoE, Rules of Court (1 January 2020), Rule 62A.1(c). It is only superficially oxymoronic that resolutions of friendly settlements require adversarial proceedings.
} 
What might the European Court do? The Court's position is somewhere between tribunals that make decisions on a case-by-case basis and develop their own case-law (as is typical for Common Law courts and the European Court) and Civil Law courts that (like the European Court) are not bound by precedent. Civil law courts, relatively unlike Common Law courts, typically operate under codes (or statutes) that establish the governing rules. Unlike the International Court of Justice, whose governing rules were established by an international treaty (the Statute of the International Court of Justice), the European Court's operating rules are largely exempt from treaty. The relative lack of a governing treaty provides the European Court with the opportunity to clarify its own internal procedures. In fact, the European Court has its own "Rules of Court" that have been amended several times since they were first promulgated in 1959 , and as recently as 1 January $2020 .^{23}$

I would like to propose two steps that courts, particularly the European Court, might take to handling evidence in human rights cases in the absence of applicable statutory or treaty law. First, the Court should articulate in its decisions, as clearly as possible, its presumptions and rationales for the handling of evidence. Rather than ignoring the issue or engaging in sleight-of-hand techniques, the Court might—among other options—state for example in the case of Lautsi:

- The state (or applicant) had the burden of proving to the Court's satisfaction the following assertions and failed (or succeeded) to prove them:

- Assertion 1 ...

- Assertion $2 \ldots$

- Assertion $3 \ldots$

- The state (or applicant) had the burden of proving to the Court's satisfaction that the state's infringement on the right to manifest religion or belief was proportionate and failed (or succeeded) to do so for the following reasons:

- Reason $1 \ldots$

- Reason $2 \ldots$

- Reason $3 \ldots$

- The Court has been provided no social-scientific evidence regarding the effect on children of the positing of religious symbols in public school classrooms;

- The Court would have found such evidence probative; 
- The Italian state (or the applicants) had the responsibility of providing such evidence;

- The Court draws (or does not draw) adverse inferences from the state's (or applicants') failure to provide such evidence.

In other words, in any important case that turns on the presence or absence of evidence, the Court should issue a motivated decision that explains its handling of critical evidentiary matters. As Dahlab and Lautsi reveal, the way that evidence (or lack thereof) is handled by the Court ultimately is the foundational basis of the decision even though it is not explained as such.

Second, and in the longer run, the Court should establish a working group of experts (whether members of the Court or outside experts or both) to develop and articulate basic procedures regarding evidence to be included in the Rules of Court. The revised Rules of Court should provide the clearest guidelines possible to identify its role, if any, in fact-gathering and to explain to applicants and to states what is expected of each of them in terms of providing sufficient evidence to support their assertions.

All sentient jurists in all jurisdictions are aware of the many difficulties surrounding the problems of finding the truth, attributing responsibility to parties, deciding fairly between competing parties, justifying exceptions to rules, and articulating clear standards in a world filled with vagueness and inconsistency. Any attempt to articulate comprehensive standards will no doubt fall short of what might be desired. But there nevertheless is a critical difference between recognizing the limitations of drafting complete guidelines and abandoning standards in favour of intuition, hunches, and impressions. While we cannot expect perfection or completeness in suggesting that the Court develop clearer standards, we might nevertheless hope for improvement and greater clarity. 